\title{
Screen time dengan konsumsi sayur dan buah serta kenaikan berat badan pada mahasiswa Fakultas Ilmu Kesehatan
}

\author{
Rossy Pratiwi ${ }^{\mathrm{a}, \mathrm{I}}$, Nur Lathifah Mardiyati ${ }^{\mathrm{a}}$ \\ aFakultas Ilmu Kesehatan Universitas Muhammadiyah Surakarta, Jl. A.Yani Tromol Pos I Pabelan Kartasura, \\ Surakarta, Jawa Tengah, Indonesia \\ ${ }^{1}$ rossypratiwi10@gmail.com* \\ *korespondensi penulis
}

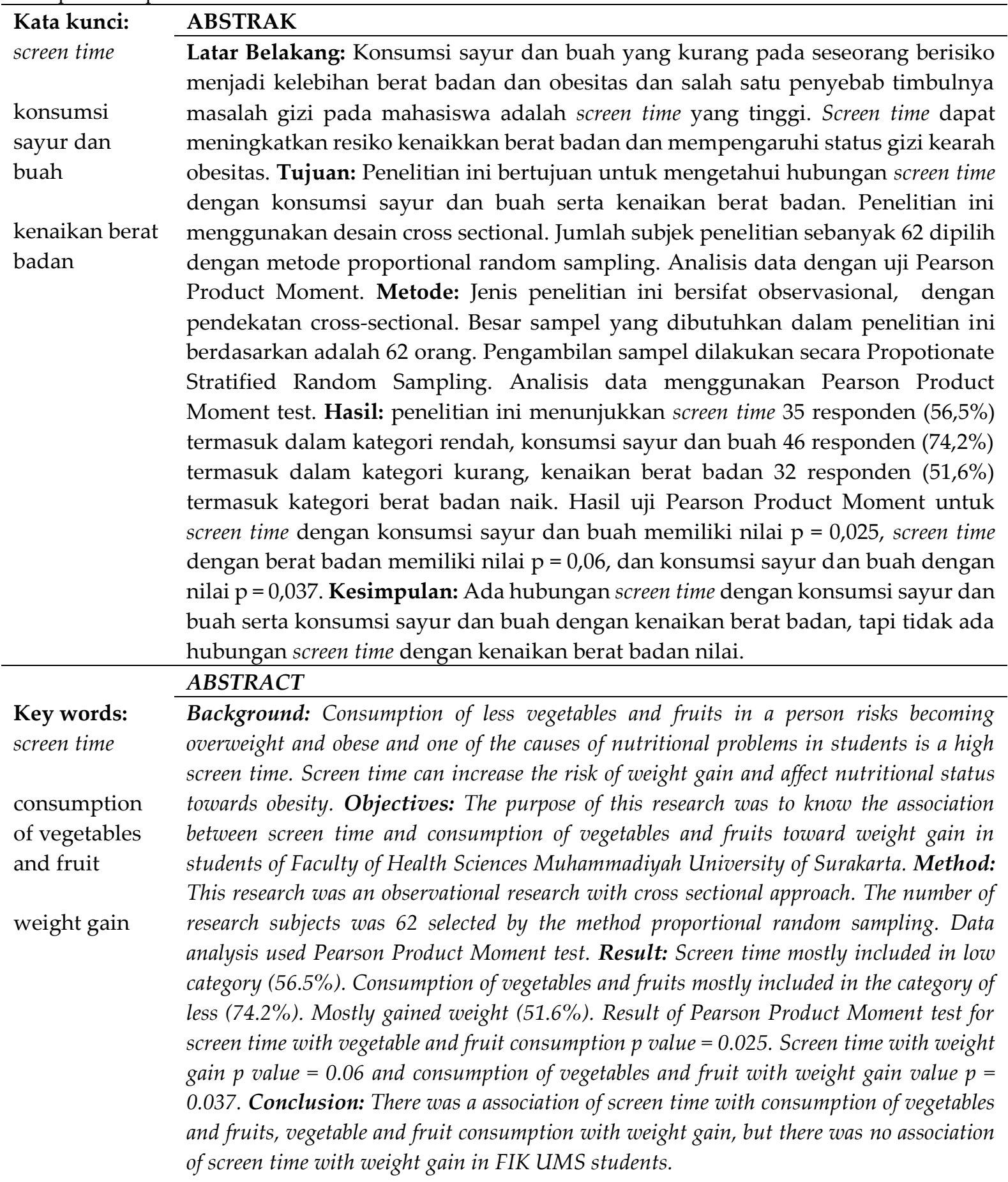

This is an open access article under the CC-BY-SAlicense. 


\section{Pendahuluan}

Mahasiswa adalah seseorang yang berusia 19 sampai 28 tahun, dimana pada usia ini menjadi dasar masa perpindahan dari masa remaja ke masa dewasa ${ }^{12}$. Pada masa usia ini faktor gizi memiliki peran untuk meningkatkan ketahanan fisik dan produktivitas kerja, dimana gizi bukan hanya berpengaruh pada derajat kesehatan tetapi juga dapat mendukung kualitas kecerdasan intelektual pada manusia ${ }^{4}$. Kehidupan mahasiswa menyebabkan terjadinya perubahan pola makan. Pada usia dewasa pola makan biasanya akan menjadi pedoman kebiasaan perilaku makan yang menetap dan sulit untuk diubah untuk usia selanjutnya ${ }^{2}$. Hal inilah yang menyebabkan mahasiswa termasuk golongan yang rentan terhadap status gizi ${ }^{15}$. Data Riskesdas 2013 di Jawa Tengah menunjukkan bahwa prevalensi obesitas pada kelompok 15 tahun keatas mencapai 28,97\%, sedangkan kejadian obesitas di Kota Surakarta sebanyak 32,5\%. Hal tersebut menunjukkan bahwa prevalensi di kota Surakarta lebih tinggi dibandingkan prevalensi Jawa Tengah.

Salah satu faktor penyebab obesitas adalah gaya hidup pada mahasiswa yang lebih banyak menghabiskan waktu dengan gadget, laptop dan televisi. Durasi yang dihabiskan untuk kegiatan di depan layar seperti menonton televisi, menggunakan komputer, laptop, handphone dan bermain video game disebut dengan screen time $e^{5}$ Penelitian Pramadhan menyebutkan bahwa 87,50 persen siswa sekolah temasuk dalam kategori high screen time ${ }^{11}$. Kegiatan menonton televisi dapat meningkatkan konsumsi energi seperi makanan ringan dan mengemil, sehingga mengakibatkan ketidak seimbangan energi positif dan berpotensi meningkatkan berat badan, hal ini disebabkan oleh kegagalan individu mengenali atau mencatat sinyal rasa kenyang saat menonton televisi sehingga menyebabkan asupan energi menjadi tinggi.

Sayur dan buah merupakan sumber zat gizi mikro yang diperlukan untuk proses metabolisme tubuh 6 . Masyarakat Indonesia dianjurkan untuk mengonsumsi sayur dan buah 250 gram per hari dan 150 gram per hari sesuai dengan rekomendasi Pedoman Gizi Seimbang 6 . Berdasarkan Survey Konsumsi Makan Individu Provinsi Jawa Tengah (2014), diketahui rata-rata konsumsi sayur dan buah penduduk usia 19-55 tahun 42,6 gram per orang per hari. Hasil ini dapat membuktikan bahwa rata-rata konsumsi sayur dan buah penduduk di Provinsi Jawa Tengah masih tergolong rendah jika dibandingkan dengan rekomendasi Pedoman Gizi ${ }^{14}$.

Kegiatan di depan layar akan menyebabkan peningkatan waktu tidak aktif. Penelitian menunjukkan bahwa peningkatan waktu yang dihabiskan untuk aktifitas tidak aktif dapat meyebabkan kenaikan berat badan dan meningkatkan resiko obesitas ${ }^{8}$. Diketahui ada hubungan bermakna antara screen time dengan status gizi ${ }^{17}$.

Hasil survey pendahuluan yang telah dilakukan pada 20 mahasiswa di Fakultas Ilmu Kesehatan Universitas Muhammadiyah Surakarta didapatkan bahwa mahasiswa dengan durasi screen time diatas rata-rata sebesar $80 \%$ dan mahasiswa dengan durasi dibawah ratarata sebesar $20 \%$. Selain itu didapatkan bahwa mahasiswa dengan konsumsi sayur dan buah kurang sebesar 85\% dan mahasiswa dengan konsumsi sayur dan buah baik sebesar 15\%. Berdasarkan uraian tersebut maka peneliti tertarik meneliti tentang hubungan screen time dengan konsumsi sayur dan buah serta kenaikan berat badan pada mahasiswa Fakultas Ilmu Kesehatan Universitas Muhammadiyah Surakarta. 


\section{Metode}

Jenis penelitian ini bersifat observasional, dengan pendekatan cross-sectional. Waktu penelitian ini dilaksanakan pada bulan September 2017. Populasi dari penelitian ini adalah seluruh Mahasiswa FIK yang berjumlah 631 orang. Besar sampel yang dibutuhkan dalam penelitian ini berdasarkan perhitungan adalah 62 orang. Pengambilan sampel dilakukan secara Propotionate Stratified Random Sampling.

Teknik pengumpulan data konsumsi sayur dan buah menggunakan formulir Semi Quantitative Food Frequency selama 1 bulan terakhir dan alat bantu food picture. Data screen time diperoleh dengan cara meminta responden untuk mengisi kuesioner screen time dari penelitian terdahulu ${ }^{10}$, data berat badan diperoleh dari hasil penimbangan dengan alat timbangan digital GEA dengan ketelitian $0,1 \mathrm{~kg}$, diambil sebanyak dua kali yaitu di awal penelitian dan di akhir penelitian dengan rentang waktu satu bulan.

Uji kenormalan data menggunakan Kolmogorov Smirnov. Hubungan screen time, konsumsi sayur dan buah serta kenaikan berat badan menggunakan uji Pearson Product Moment.

\section{Hasil dan Pembahasan}

Berdasarkan Tabel 1 dapat diketahui bahwa karakteristik responden dalam penelitian ini sebagian besar perempuan (77,4\%), dan sebagian besar berumur 19 tahun $(72,6 \%)$ hal ini berarti bahwa sebagian besar responden tergolong dalam kategori umur dewasa awal.

\begin{tabular}{|c|c|c|}
\hline Karakteristik $(n=62)$ & $\mathbf{n}$ & $\%$ \\
\hline \multicolumn{3}{|l|}{ Jenis Kelamin } \\
\hline Laki-laki & 14 & 22,6 \\
\hline Perempuan & 48 & 77,4 \\
\hline \multicolumn{3}{|l|}{ Usia (Tahun) } \\
\hline 19 & 45 & 72,6 \\
\hline 20 & 16 & 25,8 \\
\hline 21 & 1 & 1,6 \\
\hline
\end{tabular}

Berdasarkan Tabel 2 diketahui responden dalam penelitian ini memiliki nilai rata-rata durasi screen time sebesar 316,30 $\pm 199,16$ menit dengan nilai maksimal 874,28 menit yang tergolong dalam kategori durasi screen time tinggi dan nilai minimal 21,42 menit yang tergolong dalam kategori durasi screen time rendah. Kategori screen time dikatakan rendah jika durasi $<317$ menit/hari dan tinggi jika durasi $\geq 317$ menit/hari. Distribusi responden menurut durasi screen time dapat dilihat pada Tabel 2.

Tabel 2. Distribusi Responden menurut Screen Time

\begin{tabular}{ccc}
\hline Kategori & $\mathrm{n}$ & $\%$ \\
\hline Rendah & 35 & 56,5 \\
Tinggi & 27 & 43,5 \\
\hline Total & 62 & 100 \\
\hline
\end{tabular}


Responden yang memiliki screen time dalam kategori rendah $<317$ menit/hari sebesar $56,5 \%$ dan screen time tinggi $\geq 317$ menit/hari sebesar $43,5 \%$. Durasi screen time yang rendah kemungkinan dapat dipengaruhi oleh kegiatan mahasiswa yang padat seperti jadwal kuliah dari pagi hingga sore.

Gambar 1 menunjukan rata-rata screen time tertinggi adalah pada hari Minggu dan yang terendah adalah hari Jumat. Hal ini kemungkinan disebabkan karena hari minggu merupakan hari libur sehingga responden memiliki lebih banyak waktu luang yang memungkinkan untuk melakukan aktivitas di depan media elektronik.

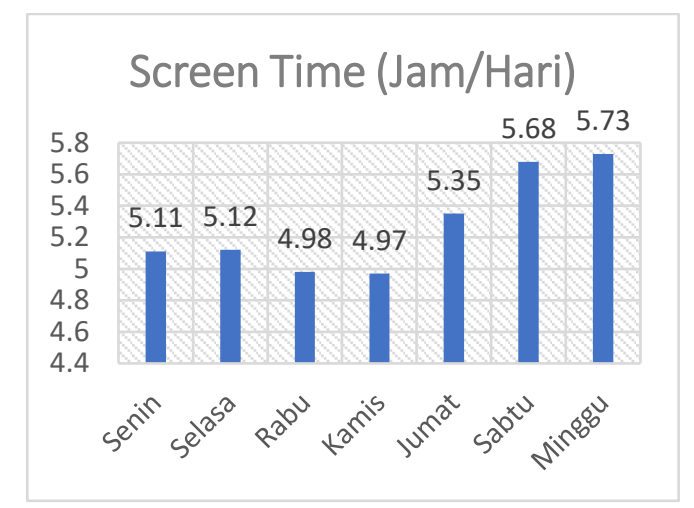

Gambar 1. Screen time selama satu minggu

Jika ditinjau berdasarkan hari kuliah, sebaran screen time pada hari Senin, Selasa, Rabu, Kamis, dan Jumat cenderung seimbang. Hal ini karena responden menghabiskan sebagian besar waktunya untuk belajar di kampus. Rata-rata screen time hari sabtu lebih tinggi dari hari kuliah lainnya karena pada hari Sabtu sebagian responden ada yang libur kuliah dan sebagian lainnya melakukan kegiatan organisasi di kampus sehingga memiliki waktu luang yang lebih banyak untuk screen time.

Gambar 2 menunjukan sebagian besar responden menghabiskan waktu untuk menggunakan HP $71 \%$ dan sebagian kecil responden bermain play station $1 \%$. Hal ini disebabkan sebagian besar responden adalah perempuan sehingga cenderung jarang bermain play station.

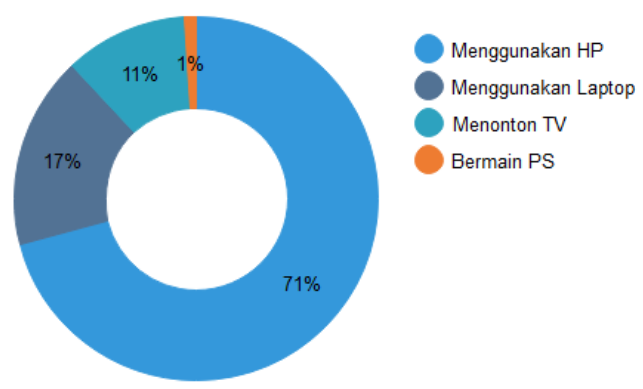

Gambar 2. Jenis kegiatan screen time selama satu minggu

Tabel 3 menunjukkan bahwa mayoritas responden memiliki konsumsi sayur dan buah dalam kategori kurang sebesar $74,2 \%$. Penelitian ini menunjukkan bahwa terdapat banyak responden yang mengonsumsi buah dan sayur tidak sesuai dengan anjuran yang diberikan. 
Tabel 3. Distribusi Responden menurut Konsumsi Sayur dan Buah

\begin{tabular}{ccc}
\hline Kategori & n & \% \\
\hline Kurang & 46 & 74,2 \\
Baik & 16 & 25,8 \\
\hline Total & 62 & 100 \\
\hline
\end{tabular}

Responden dalam penelitian ini memiliki nilai rata-rata kenaikan berat badan sebesar $0,10 \pm 0,96 \mathrm{Kg}$ dengan nilai maksimal $3,70 \mathrm{Kg}$ yang tergolong dalam kategori naik dan nilai minimal $-2,00 \mathrm{Kg}$ yang tergolong dalam kategori konsumsi tidak naik. Distribusi responden menurut kenaikan berat badan dapat dilihat pada Tabel 4 .

Tabel 4. Distribusi Responden menurut Kenaikan Berat Badan

\begin{tabular}{ccc}
\hline Kategori & $\begin{array}{c}\text { Jumlah } \\
(\mathrm{n})\end{array}$ & $\begin{array}{c}\text { Persentase } \\
(\%)\end{array}$ \\
\hline Tidak Naik & 30 & 48,4 \\
Naik & 32 & 51,6 \\
\hline Total & 62 & 100 \\
\hline
\end{tabular}

Tabel 4 menunjukkan mahasiswa FIK dalam 1 bulan terakhir yang mengalami kenaikan berat badan sebesar $51,6 \%$. Kenaikan berat badan pada mahasiswa yang sering terjadi dikarenakan aktivitas tubuh yang rendah akibat jadwal kuliah yang padat dari pagi hingga sore sehingga mahasiswa banyak menghabiskan waktu dengan duduk dan rata-rata mahasiswa menggunakan kendaraan ke kampus, serta frekuensi makan yang meningkat dan ditambah konsumsi makanan cepat saji ${ }^{13}$.

Tabel 5. Distribusi Screen Time dengan Konsumsi Sayur dan Buah

\begin{tabular}{lccccc}
\hline Screen & \multicolumn{3}{c}{ Konsumsi Sayur dan Buah } & \multirow{2}{*}{$\mathrm{p}$} \\
\cline { 2 - 5 } Time & \multicolumn{2}{c}{ Kurang } & \multicolumn{2}{c}{ Baik } & \\
\cline { 2 - 5 } & $\mathrm{n}$ & $\%$ & $\mathrm{n}$ & $\%$ & \\
\hline Rendah & 25 & 71,4 & 10 & 28,6 & 0,025 \\
Tinggi & 21 & 77,8 & 6 & 22,2 & \\
\hline
\end{tabular}

Tabel 5 menunjukkan bahwa responden yang memiliki screen time tinggi dengan konsumsi sayur dan buah kurang yaitu sebesar 77,8\%. Berdasarkan uji Pearson product moment didapatkan nilai $\mathrm{p}=0,025(\mathrm{p}<0,05)$ yaitu ada hubungan yang signifikan antara screen time dengan konsumsi sayur dan buah dengan nilai $\mathrm{r}=-0,3$ yaitu arah hubungan negatif dengan kekuatan hubungan yang cukup kuat.

Hasil penelitian ini sejalan dengan penelitian Al-Hazzaa, dkk., yang menyebutkan bahwa terdapat hubungan antara tingginya screen time dengan rendahnya konsumsi sayur dan buah ${ }^{1}$.

Durasi screen time paling tinggi adalah penggunaan smartphone, komputer dan laptop, hal ini berkaitan dengan kegiatan mahasiswa dalam membuat tugas kuliah dan kemudahan akses internet yang dapat digunakan di mana saja seperti melakukan streaming serta mahasiswa juga aktif dalam menggunakan media social seperti instagram, facebook dan twitter yang memiliki banyak iklan makanan fast food. Paparan iklan yang memiliki tayangan makanan dan minuman fast food yang menarik akan menyebabkan banyak orang lebih cenderung ingin mencoba makanan dan minuman tersebut ${ }^{8}$. 
Tabel 6 menunjukkan bahwa responden yang memiliki screen time tinggi mengalami kenaikan berat badan sebesar 59,3\%, dan screen time rendah mengalami kenaikan berat badan sebesar $57,1 \%$. Hasil menunjukkan bahwa tidak ada hubungan screen time dengan kenaikan berat badan dengan nilai $\mathrm{r}=-0,2$ yaitu arah hubungan negatife dengan kekuatan hubungan yang cukup kuat, tetapi ada kecenderungan hubungan screen time dengan kenaikan berat badan.

Tabel 6. Distribusi Screen Time dengan Kenaikan Berat Badan

\begin{tabular}{lccccc}
\hline Screen & \multicolumn{3}{c}{ Kenaikan Berat Badan } & \multirow{2}{*}{$\mathrm{p}$} \\
\cline { 2 - 5 } Time & \multicolumn{2}{c}{ Tidak Naik } & \multicolumn{2}{c}{ Naik } & \\
\cline { 2 - 5 } & $\mathrm{n}$ & $\%$ & $\mathrm{n}$ & $\%$ & \\
\hline Rendah & 15 & 42.9 & 20 & 57,1 & 0,060 \\
Tinggi & 11 & 40,7 & 16 & 59,3 & \\
\hline
\end{tabular}

Hal ini dikarenakan banyak faktor yang dapat menyebabkan kenaikan berat badan salah satunya adalah kurangnya aktifitas fisik, dari hasil kuesioner kegiatan sehari-hari yang dikumpulkan selama 1 minggu diketahui sebanyak 83,8\% responden menggunakan kendaraan saat pergi ke kampus, kemudian diikuti oleh jadwal kuliah yang padat dan tugas yang harus dikerjakan hingga larut malam, hal ini menyebabkan mereka lebih banyak menghabiskan waktu untuk duduk di kelas dan malas berolahraga, sehingga aktifitas fisik menjadi rendah.

Dalam menyelesaikan tugasnya biasanya responden memiliki kebiasaan mengonsumsi makanan fast food. Fast food merupakan makanan yang mengadung kalori tinggi, rendah vitamin, mineral dan serat, sehingga jika dikonsumsi dalam jangka waktu tertentu dan dalam jumlah yang besar dapat menyebabkan kelebihan kalori yang berakibat kenaikan berat badan dan obesitas ${ }^{7}$. Ada hubungan signifikan antara frekuensi konsumsi makanan cepat saji (fast food) dengan kenaikan berat badan pada mahasiswa9.

Tabel 7. Distribusi Konsumsi Sayur dan Buah dengan Kenaikan Berat Badan

\begin{tabular}{cccccc}
\hline Konsumsi & \multicolumn{4}{c}{ Kenaikan berat badan } & \multirow{2}{*}{ p } \\
\cline { 2 - 5 } $\begin{array}{c}\text { Sayur dan } \\
\text { Buah }\end{array}$ & $\mathrm{n}$ & $\%$ & $\mathrm{n}$ & $\%$ & \\
\cline { 2 - 5 } Tidak naik & 34,8 & 30 & 65,2 & 0 \\
\hline Kurang & 16 & 62,5 & 6 & 37,5 & \\
Cukup & 10 & &
\end{tabular}

Tabel 7 menunjukkan bahwa responden yang memiliki konsumsi sayur dan buah kurang mengalami kenaikan berat badan $65,2 \%$, dan responden yang memiliki konsumsi sayur dan buah baik tidak mengalami kenaikan berat badan $62,5 \%$. Hasil ini menunjukkan bahwa ada hubungan signifikan antara screen time dengan kenaikan berat badan dengan nilai $\mathrm{r}=-0,3$ yaitu arah hubungan negatif dengan kekuatan hubungan yang cukup kuat.

Ada hubungan rendahnya konsumsi sayur dan buah dengan terjadinya kegemukan pada mahasiswa. Buah dan sayuran memiliki kepadatan energi yang rendah karena memiliki kandungan air yang tinggi, kandungan energi yang rendah, dan kandungan serat makanan yang tinggi. Oleh karena itu, buah dan sayur dianggap mampu meningkatkan rasa kenyang dan mengurangi rasa lapar. Buah dan sayur juga mengandung flavonoid dan kelompok phytochemical nonnutritive yang mungkin memiliki efek antiobesitas. Hal ini membuat buah 
dan sayuran baik jika dimasukkan dalam pesan kesehatan masyarakat untuk mencegah obesitas $^{15}$.

Konsumsi buah dan sayur sangat berperan penting bagi kesehatan tubuh. Hal ini juga dapat digunakan sebagai pengendalian dan pencegahan overweight dan obesitas pada remaja ${ }^{3}$. Konsumsi buah dan sayuran berhubungan secara signifikan pada perubahan berat badan, pola diet yang ditandai dengan jumlah tinggi buah dan sayuran berhubungan dengan peningkatan berat badan yang lebih kecil dan resiko yang lebih rendah dari kelebihan berat badan dan obesitas ${ }^{18}$.

\section{Kesimpulan dan Saran}

Ada hubungan signifikan antara screen time dengan konsumsi sayur dan buah, konsumsi sayur dan buah dengan kenaikan berat badan dan tidak ada hubungan antara screen time dengan kenaikan berat badan pada mahasiswa FIK di Universitas Muhammadiyah Surakarta. Perlu diadakan penyuluhan pada setiap fakultas atau membuat poster mengenai ajakan konsumsi sayur dan buah serta membatasi kebiasaan screen time sehingga diharapkan mahasiswa dapat mengurangi durasi screen time dan meningkatkan konsumsi sayur dan buah agar tidak terjadi peningkatan berat badan yang berlebihan sehingga berakibat pada status gizi obesitas.

\section{Reference}

1. Al-Hazzaa, H. M., Al-Sobayel, H. I., Abahussain, N. A., Qahwaji, D. M., Alahmadi, M. A., Musaiger, A. O. 2013. Association of dietary habits with levels of physical activity and screen time among adolescents living in Saudi Arabia. J Hum Nutr Diet.

2. Brown, JE. 2005. Nutrition Through the Life Cycle (edisi kedua). Thomson Wadsworth. USA.

3. Buijsse, B., Feskens, EJM., Schulze, MB., Forouhi, NG., Wareham, NJ., Sharp, S., Palli, D., Tognon, G., Halkjaer, J., Tjonneland, A. 2009. Fruit and vegetable intakes and subsequent changes in body weight in European populations: results from the project on Diet, Obesity, and Genes. The American Journal of Clinical Nutrition. 90(1) : 202-207.

4. Hidayat, Syarief. 1997. Membangun SDM Berkualitas. Suatu Telahan Gizi Masyarakat dan Sumber Daya Keluarga. IPB. Bogor.

5. Houghton, S., Hunter, SC., Rosenberg, M., Wood, L., Zadow, C., Martin, K., Shilton, T. 2015. Virtually impossible: limiting Australian children and adolescents daily screen based media use. BMC Public Health. 15:5 1471-2458/15/5.

6. Kementerian Kesehatan RI. 2014. Pedoman Gizi Seimbang. Jakarta.

7. Khasanah, N. 2012. Waspadai Beragam Penyakit Degeneratif Akibat Pola Makan. Cetakan Pertama Yogyakarta: Penerbit Laksana.

8. Lipsky, LM., Lannotti, RJ. 2012. Associations of Televition Viewing with Eating Behaviors in the 2009 Health Behaviour in School-aged Children Study. Arch Pediatr Adolesc Med. 166(5):465-72.

9. Nurlita, N., Mardiyati, NL. 2016. Hubungan Frekuensi Konsumsi Makanan Cepat Saji (Fast Food) dengan Tempat Tinggal pada Mahasiswa FIK dan FT UMS. Jurnal. 2579-9622.

10. Nasution, I. 2016. Screen Time, Asupan Lemak Dan Serat Serta Status Gizi Siswa Sekolah Dasar Di Kota Bogor. Fakultas Ekologi Manusia. ITB. Bogor. 
11. Pramadhan, Y. 2016. Keterkaitan Screen Time, Aktivitas Fisik, Asupan Zat Gizi Dengan Status Gizi Dan Tingkat Kecukupan Energi Pada Siswa Sd Gadog 03 Bogor. Skripsi. Fakultas Ekologi Manusia. IPB. Bogor.

12. Siswoyo, Dwi. 2007. Ilmu Pendidikan. Yogyakata: UNY Press.

13. Suryanti R, Jafar N, Syan A. 2013. Gambaran jenis dan jumlah konsumsi fast food dan soft drink pada mahasiswa obesitas di Universitas Hasanudin. Skripsi. Fakultas kesehatan masyarakat Universitas Hasanudin. Makassar.

14. Survey Konsumsi Makan Individu. 2014. Studi Diet Total: Survey Konsumsi Makan Individu Provinsi Jawa Tengah. Badan Penelitian dan Pengembangan Kesehatan. Jakarta.

15. Thamrin, MH., Kusharto, CM., Setiawan, B. 2008. Kebiasaan Makan dan Pengetahuan Reproduksi Remaja Putri Peserta Pusat Informasi dan Konseling Kesehatan Reproduksi Remaja (PIK-KRR). Jurnal Gizi dan Pangan: Bogor.

16. Wardhani, D,K. 2015. Keterkaitan antara Konsumsi Buah dan Sayur serta Gaya Hidup dengan Kejadian Kegemukan pada Mahasiswa TPB-IPB. Skripsi. Fakultas Ekologi Manusia. IPB. Bogor.

17. Worang, TY., Joy, A., Rattu, M., Jootje, ML., Umboh. 2017. Hubungan Antara Aktivitas Fisik, Screen Time Dan Konsumsi Minuman Ringan Dengan Status Gizi Pada Siswa SMA Kristen Eben Haezar Manado. Thesis. Fakultas Kesehatan Masyarakat. Universitas Sam Ratulangi. Manado.

18. Schulz, MB., Fung, TT., Manson, JE., Willett, W.C, Hu, FB. 2006. Dietary Patterns and Changes in Body Weight in Women. Obesity (Silver Spring).14 (2):1444-53. 